\title{
The Development of Teaching Materials with Mind Mapping Methods Literary Literacy Oriented and Character Education to Improve Understanding of Literary History
}

\author{
Ade Asih Susiari Tantri ${ }^{*}$, Putu Mas Dewantara² \\ 1,2 Universitas Pendidikan Ganesha
}

A R T I C L E I N F O

Article history:

Received 20 July 2018

Received in revised

form

10 August 2018

Accepted 15 October 2018

Available online 28

November 2018

Keywords:

teaching materials, mind mapping, literary

literacy, and character

education.

\begin{abstract}
A B S T R A C T
This study aims to develop teaching materials using mind mapping method oriented to literary and character education in a valid, practical, and effective Literature History course. There are three aspects that used to measure the instructional material developed, namely: 1) the content of teaching materials validity will be assessed by experts that adjusted to the supporting theory while construct validity is assessed by experts by paying attention to the relevance and suitability of the developed teaching materials; 2) practicality of the developed teaching material is measured by its implementation in lectures in class by using the instrument of questionnaire responses of students and lecturers; 3) effectiveness of instructional materials was measured using multiple choice tests. The development of this teaching material follows the procedure for product development from Plomp, namely: 1) initial investigation, 2) design, 3) realization/ construction, 4) test, evaluation, and revision; and 5) implementation. Given the time constraints, this study did not arrive at the implementation stage but only arrived at limited trials. From the results of the study, the instructional material developed has met the criteria of valid, practical, and effective. Whereas from the results of limited trials, the instructional material developed effectively increases the understanding of Literature History in PBSI semester I students in the academic year 2018-2019. This is evident by increasing of the percentage of students getting $\mathrm{B}+, \mathrm{A}_{-}$, that is $62 \%$ in the first cycle become $80 \%$ in second cycle. It is already above the percentage that have been achieved and even exceeding the target, that is $70 \%$ of students get $B+, A-$, and $A$ in the beginning of study.
\end{abstract}

\section{Introduction}

History of literature is a part of literary science that is intertwined between literary theory and literary criticism. So, understanding and deepening this course is very important for understanding and deepening other literary studies. But in reality, students' understanding of this course is still not satisfactory. Based on the UAS (Semester Final Examination) value data taken from the Puskom Undiksha information system section on January 18,2018 , as many as $50.88 \%$ of students get B +, A-, and A. This indicates students' understanding of the material taught to the eyes this lecture on literary history has not been satisfactory.

In addition, from the results of interviews with lecturers in History Literature courses, namely the low understanding and value of students due to the shallow material discussed in the presented paper. This is also due to the lack of source books and the lack of creativity of students looking for reference sources. In line with the opinion of Rismawati (2017: 1), namely "this is due to the lack of available textbooks, which are easy for students to learn with simple and relevant examples". In addition, many 
students simply copy other people's writings from the internet, without analyzing the truth and accuracy of the source. This is because of the low awareness of students working on tasks and responsibilities as students. This problem also reflects the character of the student needs to be nurtured.

From the results of interviews with several students, the low level of understanding and value obtained by students is caused by several factors, namely: 1) difficult to remember material that has been read or explained; 2) limited source books; 3) lazy looking for sources and materials for papers presented; 4) bored with the lecture learning model and discussion; and 5) the presentation of material from the group whose presentation is not clear.

In connection with the above problems, it is necessary to develop teaching materials using the mind mapping method oriented to literacy and character education which focuses on students: 1) able to remember as much information as possible from reading or listening; 2) being a literate person; 3) have broad insight; 4) smart; 5) able to think critically; 6) can solve problems quickly; 7) can communicate well; and 8) have good character.

Making the Indonesian people literate, especially the younger generation is the dream of the Indonesian people. According to Lipton, L and D. Hubble (2016: 125), knowledge that continues to increase in the 20th century, causes teachers to be able to encourage students to recognize that reading is a very satisfying personal activity, information seeking, and a way to connect with the world. Therefore, the teacher must create a literacy-based learning.

The school literacy movement programmed by the Ministry of Education and Culture is mandatory in all schools, without exception in universities. School literacy is "the ability to access, understand, and use something intelligently through various activities, including reading, seeing, listening, writing, and / or speaking" (Kemendikbud, 2016). Therefore, to improve students' insight and critical thinking skills in understanding and deepening literature, lecturers need to develop teaching materials using mind mapping methods that are oriented towards literacy and character education.

The low memory of students about what is read and listened to, can be overcome by applying the mind mapping method. Buzan, T (2010: 4) argues that mind map is the easiest way to enter information into the brain, and to extract information from the brain. In line with the above opinion, according to Devi, R.S, et al (2015), "Mind mapping method is one of the learning methods that can help students to organize knowledge and concepts in the brain well". The mind map method has several advantages that can help solve problems faced both in the fields of understanding, creativity, and memory.

Referring to the problems of student character that need to be fostered. Ki Hajar Dewantara (in Wibowo, A, 2013: 35), "the success of true education is to produce civilized human beings, not those who are cognitively and psychomotorically intelligent but poor in character or character. "This coaching can be done through appreciating literature. According to (Haryadi, 2011: 5), the formation of national character is not only through the values contained in literary works, but appreciative literary learning, such as reading, listening, and watching literary works are loaded with character education.

Guided by character education according to the Ministry of National Education (2011: 9), literary history teaching materials developed will be designed with reference to 11 character values, namely: religious, disciplined, hard work, creative, independent, curiosity, national spirit, love of land water, love to read, care for the environment, and responsibility. Given the limitations of time, the Literature History teaching material that will be developed is limited to the theme of the new Balai Pustaka and Pujangga Baru. The formulation of the problem in this study, namely 1) How is the development of literary history teaching materials using mind mapping oriented literary literacy and character education methods that are valid, practical, and effective? and 2) Are teaching materials using mind mapping method oriented to literacy and character education developed to improve the understanding of literary history of students in the first semester of the 2018-2019 academic year PBSI Study Program?.

\section{Method}

The approach used in this research is Research and Development / R \& D. The stages in this study refer to the theory of the development of Plomp which consists of five stages namely preliminary investigation, design, realization / construction, tests, evaluations, and revisions (test, evaluation, and revision), and implementation (Plomp, 1997). It should be emphasized that this research is limited to only stage 4 , namely until the stage of testing, evaluation, and revision.

The research data to be collected in the form of information relating to: 1) analysis of the needs of students and lecturers during the lecture history of literature collected by the technique of unstructured interviews and non-participant observation; 2) the process of developing teaching materials; 3 ) the validity of teaching materials is measured by content validity and construct validity; 4 ) the practicality of teaching material is measured by its implementation in lectures in class by using student and lecturer 
response questionnaire instruments and observation sheets by observers; and 5) the effectiveness of teaching materials measured by multiple choice tests.

The collected data was analyzed descriptively qualitatively. The average total score is changed to a qualitative value using the following criteria.

$\begin{array}{ll}3.5 \leq \mathrm{Sr} \leq 4.0 & \text { Very Valid } \\ 2.5 \leq \mathrm{Sr} \leq 3.5 & \text { Valid } \\ 1.5 \leq \mathrm{Sr} \leq 2.5 & \text { Invalid } \\ 1.0 \leq \mathrm{Sr} \leq 1.5 & \text { Very Invalid }\end{array}$

Teaching materials in this study must at least reach a valid category to be used in learning while the developed teaching material can be said to have practicality if the minimum average score is included in the practical category. The average total score is changed to a qualitative value using the following criteria.

$3.5 \leq \mathrm{Sr} \leq 4.0$
$2.5 \leq \mathrm{Sr} \leq 3.5$
$1.5 \leq \mathrm{Sr} \leq 2.5$
$1.0 \leq \mathrm{Sr} \leq 1.5$ Very practical

Practical

Not Practical

Very Not Practical

\section{Results and Discussion}

\section{Preliminary Investigation}

This initial investigation was conducted to find out the causes of the students' low ability to understand the history of literary material, especially material concerning the literary class. From the results of interviews with lecturers in literary history courses, Literature History material was taken from modules that still refer to the 2012 curriculum. In addition to teaching materials, the methods used by lecturers are discourse, question and answer, and discussion methods.

In addition, students were also interviewed to find out how the teaching and learning process (PBM) in Literature History courses. Of the 20 students (classes A and B) interviewed stated that: 1) the method used by the lecturer was discourse and discussion; 2) students sometimes feel bored and have difficulty concentrating when PBM; 3) it is difficult to memorize the names of authors and their works; and 4$)$ it is difficult to distinguish the characteristics of literature in each class.

In addition to interviews, questionnaires were given to students to find out about teaching materials and PBM in Literature History courses and student expectations related to PBM problems in Literature History courses. First, $84 \%$ of students stated that they need to be given History Literature teaching materials that contain literary appreciation. Second, $71 \%$ of students stated that there is a need for literary literacy in the learning process. Third, $94 \%$ of students stated that a variety of learning methods was needed. From the results of the initial investigation, it indicates that it is necessary to develop the History Literature teaching material that is oriented towards literacy activities.

\section{Design}

There are several steps taken to design the teaching material developed, as follows.

a. Analyzing syllabus. Analysis was carried out on learning outcomes (CP), CP achievement indicators, and subject matter of learning.

b. Arrange the material framework to be developed. The material framework was made so that it was easier to develop the Balai Pustaka and Pujangga Baru material.

c. Developing Central Library materials. The material is taken from the latest source books as well as articles related to literature and the maximum force of the last 10 years.

d. Prepare student work papers. The task of the individual is to make a concept map of the material that has been read. The task of the group is to read the synopsis of the novel or short story and then look for character values that can be imitated by students in everyday life.

e. Make mind mapping or concept maps.

f. Develop evaluation tools to determine students' understanding of the material being taught.

\section{Realization/Construction}

In this stage, Literature History teaching materials are developed, especially literary material from the Balai Pustaka and literature generation of the Pujangga Baru class according to the analysis of the needs of lecturers and students. Learning outcomes and objectives adjust to the KKNI curriculum made by the Indonesian Language and Literature Education Study Program. From these achievements and objectives, teaching materials were developed using the mind mapping method. Literacy literature activities are carried out at the beginning of learning by directing students to read novels for 15 minutes. Finally, students are assigned to read the synopsis of one of the novels from the Balai Pustaka class and 
the Pujangga Baru class and then look for character values in the story to be linked to character education in the daily lives of students.

\section{Test, Evaluation and Revision Phase}

\section{a. Validation Test for Instructional Materials and Instruments}

The content validity of the teaching material was assessed by 2 experts. Validation of this content is adapted to the supporting theory while construct validity is assessed by experts with regard to the relevance and appropriateness of the instructional materials developed. 1Q1qaAZS 'q1234 Below is a table of results of teaching material validation by 2 experts.

Table 1. Results of Validation of Teaching Materials

\begin{tabular}{ccccc}
\hline No & Validator & Average Sroce & Criteria \\
\cline { 1 - 1 } & & Validator 1 & 3.81 & Very Valid \\
Validator 2 & & 3.79 & Very Valid \\
\hline
\end{tabular}

Based on the table above, it can be concluded that the value of construct validity of teaching materials developed in this study has met the criteria, which is very valid. Very valid because the average score of validity is at intervals of $3.5 \leq S r \leq 4.0$. In addition to testing the validity of teaching materials, the instruments before being used were also tested validly. The following is a table of results of the instrument validity test.

\section{Table 2. Results of Instrument Validation}

\begin{tabular}{llllll}
\hline No & $\begin{array}{l}\text { Research Instrument Questionnaire } \\
\text { for student responses }\end{array}$ & $\begin{array}{l}\text { Validator 1 } \\
\text { Average } \\
\text { Criteria }\end{array}$ & $\begin{array}{l}\text { Validator 2 } \\
\text { Average } \\
\text { Score }\end{array}$ & $\begin{array}{l}\text { Criteria } \\
1\end{array}$ \\
$\begin{array}{l}\text { Questionnaire for the response of } \\
\text { lecturers to teaching materials }\end{array}$ & 3.42 & Proper to use & 3.57 & Proper to use \\
2 & $\begin{array}{l}\text { Learning observation sheet with } \\
\text { teaching materials that have been } \\
\text { developed }\end{array}$ & & Proper to use & 3.60 & Proper to use \\
3 & $\begin{array}{l}\text { Material understanding test } \\
\text { Research Instrument }\end{array}$ & 3.67 & $\begin{array}{l}\text { Proper to use } \\
\text { Proper to use }\end{array}$ & 3.59 & Proper to use \\
4
\end{tabular}

Based on the table above, the research instrument used to measure the effectiveness and practicality of the instructional materials that have been developed includes the criteria for use.

\section{Effectiveness Test of Teaching Materials}

Limited tests were carried out in 2 classes, namely: class I A and I B study program Indonesian Language and Literature Education academic year 201-2019. The following is a summary of the results of the understanding test material for the New Balai Pustaka and Pujangga Baru in class A and B in the first and second cycles in the form of a pie chart.

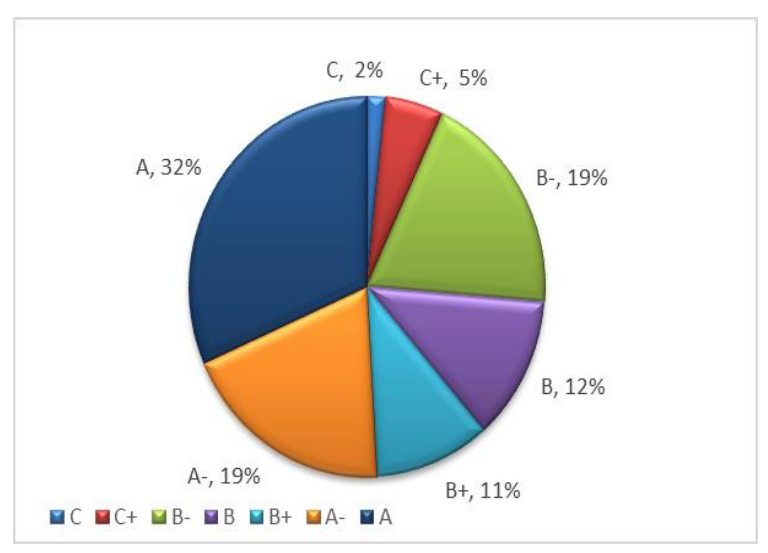

Figure 1. Percentage of Acquisition of Class A and Class B Values in Cycle 1 
Based on this pie chart, $62 \%$ of students apply B +, A-, and A. This indicates that the $70 \%$ target has not been achieved. Therefore, the implementation of learning in cycle 2 was adjusted to the results of reflection in cycle 1 by making several improvements in accordance with the handling design designed by the lecturer with the researcher.

The following is a summary of the results of the material understanding test results of the Balai Pustaka and Pujangga Baru Class I A and Class I B in cycle 2 in the form of a pie chart.

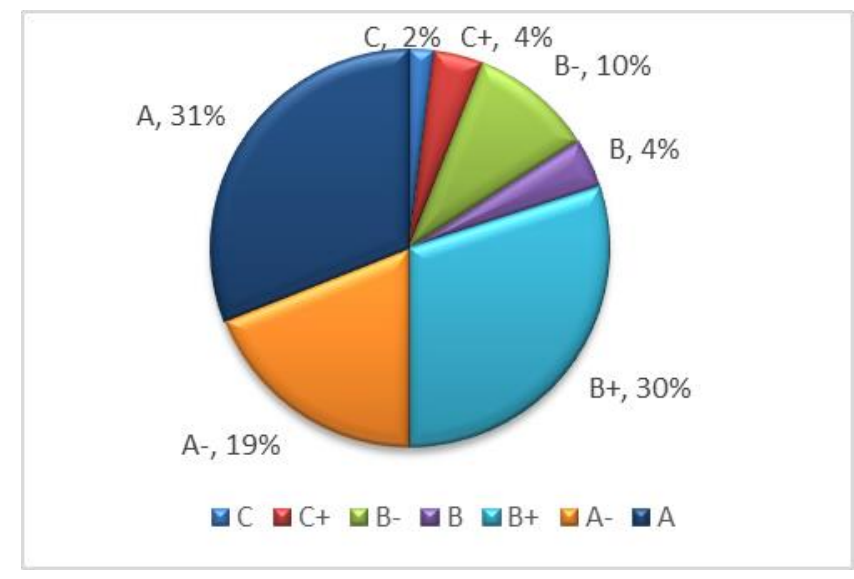

Figure 2. Percentage of Acquisition of Class A and Class B Values in Cycle 2

Based on the circle diagram above, $80 \%$ or 46 students get the values of $\mathrm{B}+, \mathrm{A}-$, and $\mathrm{A}$. This indicates that the instructional materials developed are effective to improve the understanding of the History of Literature, especially the material of the Balai Pustaka and Pujangga Baru. This is evident from the target of $70 \%$ of students getting the $\mathrm{B}+, \mathrm{A}_{-}^{-}$, and A scores set at the beginning of the study, it has been reached and even exceeds the target.

\section{Practical Test of Teaching Materials}

Practical tests are carried out so that the instructional materials developed can be implemented in a wider scope. This data is taken from the questionnaire responses of students and lecturers as users of instructional materials developed. The following is a summary of the results of the practicality of the teaching materials developed.

\section{Table 4.3 Summary of Practical Material Learning Test Results}

\begin{tabular}{llcl}
\hline No & Research Instrument & Average Score & Criteria \\
\hline 1 & Lecturer Response Questionnaire & 3.43 & Practical \\
2 & Student Response Questionnaire & 3.50 & Practical \\
\hline
\end{tabular}

There are some inputs given by the lecturers related to this teaching material. These inputs, namely 1) time must be really calculated so that the learning objectives can be achieved; 2) literary works that are read in literary literacy activities must be reproduced in kind, for example a collection of short stories, poetry and romance; and 3) character values sought not only from synopsis, but also from literary works that are read during literacy activities. This input is then used as material to improve the teaching materials developed, especially when implementing teaching materials.

The first finding in this study was that students felt very enthusiastic about expressing the material explained by the lecturer into mind mapping or concept maps. From the results of their interviews stated that their understanding and memory is better by making mid mapping compared to just listening or taking notes. They can also re-read the core learning given by the lecturer through the mid mapping they have creatively made. This finding is in line with opinion Smith, Clark, \& Conroy (2013) "by focussing on key ideas written down in your own words, and then looking for branches out and connections between the ideas, you are mapping knowledge in a manner which will help you understand and remember new information".

The second finding is the increasing desire of students to read quality novels. From the results of interviews, students claimed to have never read high-value or quality novels, occasionally students claimed to read novels, but teen novels. This certainly fosters positive value in students. High literary 
novels, such as Siti Nurbaya, Salah Asuhan, Layar Terkembang, and many more, must be known and understood by students as prospective Indonesian teachers.

The third finding, in the literature work of the Balai Pustaka and the Pujangga Baru classrooms, contains a lot of intellectual and moral values. This is certainly in accordance with the characteristics of the Balai Pustaka, namely the cultivation of moral and moral education in his literary work. Characteristics of the work of the Pujangga Baru class are the development of Indonesian culture, but the work in this generation also contains many moral messages which are certainly very good to be modeled by students. This is in line with the opinion of Wulandari (2015: 67) which states that "literary works are loaded with values of moral education as desired in character education".

Based on the findings above, it can be said that teaching materials using the mind mapping method oriented to literacy and character education are effective in increasing the understanding of the History of Literature, especially the material of the Balai Pustaka and the Pujangga Baru. In addition, the teaching materials developed were also practically used in understanding the materials of the Balai Pustaka and the Pujangga Baru.

\section{Conclusions and Suggestions}

Development of this teaching material through 5 stages, namely 1) initial investigation, 2) design of teaching materials, 3) stage of realization or construction, 4) Stage of tests, evaluations, and revisions, and 5) Limited Phase testing. From the results of limited trials, it can be said that teaching materials using the mind mapping method oriented to literacy and character education are effective in increasing the understanding of the History of Literature, especially the material of the Central Library and the New Poet Force. In addition, the teaching materials developed were also practically used in understanding the materials of the Balai Pustaka and the Pujangga Baru.

\section{Refferences}

Buzan, T. 2010. Buku Pintar Mind Map. Jakarta: PT Gramedia Pustaka Utama.

Devi, R.S, dkk. 2015. Efektivitas Metode Mind Mapping terhadap Peningkatan Pemahaman Konsep Siswa pada Mata Pelajaran IPA. Jurnal Antologi UPI. 3 (2):1-8.

Haryadi. (2011). Peran Sastra dalam Pembentukan Karakter Bangsa. Retrieved from staff.uny.ac.id/sites/.../Peranan Sastra dalam Pendidikan Karakter.doc

Kemendikbud. (2016). Panduan gerakan literasi sekolah di sekolah dasar. (P. . P. Pangesti Wiedarti, M.Appl.Ling. \& D. Kisyani-Laksono, Eds.), Direktorat Pembinaan Sekolah Dasar Direktorat Jenderal Pendidikan Dasar dan Menengah Kementerian Pendidikan dan Kebudayaan. Jakarta. Retrieved from http://repositori.perpustakaan.kemdikbud.go.id/40/1/Panduan-Gerakan-Literasi-Sekolahdi-SD.pdf.

Kementerian Pendidikan Nasional. 2011. Panduan Pelaksanaan Pendidikan Karakter. Jakarta:Pusat Kurikulum.

Plomp, T. 1997. Educational And Training System Design. Enschede: University of Twente, Faculty of Educational Science and Technology.

Rismawati. (2017). Perkembangan Sejarah Sastra Indonesia. Aceh: Bina Karya Akademika.

Smith, J., Clark, A., \& Conroy, C. (2013). Mind mapping. In Fire Risk Management (pp. 42-46). https://doi.org/10.1007/978-3-8349-4691-1_55

Wulandari, R. A. (2015). Sastra dalam Pembentukan Karakter Siswa. Jurnal Edukasi Kultura, 2(2), 63-73. Retrieved from http://jurnal.unimed.ac.id/2012/index.php/kultura/article/download/5181/4613

Wibowo. A. 2013. Pendidikan Karakter di Perguruan Tinggi. Yogyakarta:Pustaka Pelajar. 